\title{
The Effects of Partial Pressure of Oxygen upon Respiration and Nitrogen Fixation by Soybean Root Nodules
}

\author{
By F. J. BERGERSEN \\ Division of Plant Industry, C.S.I.R.O., Canberra, Australia
}

(Received 4, December 1961)

\begin{abstract}
SUMMARY
Increased oxygen tension $\left(\mathrm{pO}_{2}\right)$ caused increased respiration by excised soybean nodules of all ages. The increase took place in two steps, the first maximum occurring at about 50\% $\mathrm{O}_{2}$ and the second at 90-100\% $\mathrm{O}_{2}$ for actively nitrogen-fixing nodules. With increasing nodule age the first maximum occurred at decreasing $\mathrm{pO}_{2}$ until, when fixation ceased at about 6 weeks, this maximum had disappeared. This effect was more marked at $30^{\circ}$ than at $23^{\circ}$. The respiration of bacteroids increased with increasing $\mathrm{pO}_{2}$ with a maximum at $2-3 \% \mathrm{O}_{2}$; the curve indicated a simple saturation of the terminal respiratory pathway with $\mathrm{O}_{2}$. Increased $\mathrm{pO}_{2}$ raised nitrogen fixation by excised nodules to a maximum which corresponded to the first maximum of the respiratory response to raised $\mathrm{pO}_{2}$; higher $\mathrm{pO}_{2}$ than this decreased nitrogen fixation. Sliced nodules showed the same effect but the stimulation of fixation at the lower $\mathrm{pO}_{2}$ levels was not as great as with intact nodules. The Michaelis constant $\left(K_{m}\right)$ for nitrogen fixation by intact excised nodules was relatively unaffected by $\mathrm{pO}_{2}$ until this reached the $\mathrm{pO}_{2}$ for maximum fixation when the $K_{m}$ rose sharply. At external $\mathrm{pO}_{2}$ of $80 \%$, oxygen was shown to be a competitive inhibitor of nitrogen fixation.

An explanation of these results is offered; it is suggested that the first part of the nodule $\mathrm{O}_{2}$ consumption $/ \mathrm{pO}_{2}$ curves is due to $\mathrm{O}_{2}$ consumption by plant tissue and the second part to $\mathrm{O}_{2}$ consumption by bacteroids. The two components are separated by an $\mathrm{O}_{2}$ permeability barrier. When this barrier permits a rise in the $\mathrm{pO}_{2}$ at the bacteroids, nitrogen fixation is inhibited as oxygen competes with nitrogen for the reducing power of the bacteroids.
\end{abstract}

\section{INTRODUCTION}

Allison, Ludwig, Hoover \& Minor (1940) concluded from studies of the effects of increased oxygen tension upon nodule respiration that oxygen tension was low within the tissue of soybean root nodules. Ebertova (1959) measured low redox potentials within nodules during the period in which nitrogen was fixed. In contrast to these findings Ferguson \& Bond (1954) found that increased oxygen tension in the root medium favoured nitrogen fixation by whole nodulated plants; and Burris, Magee \& Bach (1955) found with sliced soybean nodules that oxygen tensions up to $50 \% \mathrm{O}_{2}$ stimulated fixation but that higher tensions were inhibitory. Bond (1961) reported similar effects with root nodules of non-leguminous plants.

A unified hypothesis which relates the various phases of symbiotic nitrogen fixation in legume nodules has been proposed (Bergersen, 1960b) in which it is suggested that reducing power generated in the bacteroids brings about the ultimate production of $\mathrm{NH}_{3}$ from $\mathbf{N}_{2}$. This hypothesis demands that oxygen tension at 
the surface of the bacteroids be low (much less than the tension which saturates their terminal respiratory enzymes) if aerobic terminal respiration is not to compete with $\mathbf{N}_{2}$ for their reducing power. The work to be reported here was undertaken to investigate the apparent paradox of oxygen both stimulating and inhibiting nitrogen fixation by legume nodules. In doing this the work also provided a test of one aspect of the hypothesis.

\section{METHODS}

Plant material. Lincoln variety soybeans were grown and nodule age recorded as previously described (Bergersen, 1958). Nodules were detached from the roots into beakers immersed in ice and experiments were begun within $1 \mathrm{hr}$. of picking the first nodule.

Bacteria. Rhizobium japonicum strain CC711 was used throughout and was grown on yeast-extract mannitol agar. Suspensions of bacteroids (the nodular form of the organisms) were obtained from crushed nodules as previously described (Bergersen, 1958).

Respirometry. Respiration was measured in double capillary Warburg manometers equipped with stopcocks between the fluid reservoirs and the capillaries to permit evacuation and flushing of the respirometers with various gas mixtures. In doing this the fluid was lowered to the hole of the stopcock and the respirometers evacuated and filled through both sides of the manometer. When filled, the fluid was raised and a positive pressure maintained until just before measurements began, when the excess pressure was released.

Respiration of whole and sliced nodules was measured in Warburg vessels (volume $30 \mathrm{ml}$.) containing 20 nodules and $0.25 \mathrm{ml}$. phosphate buffer $(\mathrm{M} / 15, \mathrm{pH} \mathrm{7 \cdot 0})$ with $0.2 \mathrm{ml} .40 \%(\mathrm{w} / \mathrm{v}) \mathrm{KOH}$ in the centre wells. Respiration of bacteroids was measured in the same vessels using $1.0 \mathrm{ml}$. bacteroid suspension and $1.0 \mathrm{ml}$. of $0.02 \mathrm{M}-\mathrm{Na}$ succinate or $1 \mathrm{ml}$. of phosphate buffer $(\mathrm{M} / 15, \mathrm{pH} 7 \cdot 0)$.

Preliminary tests showed that little change in $\mathrm{pO}_{2}$ due to uptake of oxygen resulted during measurement of the respiration rate during $30 \mathrm{~min}$. with bacteroids or during $1 \mathrm{hr}$. with nodules; with bacteroids the $\mathrm{pO}_{2}$ fell from 2.0 to $1.8 \%$ and from 1 to $0.9 \%$. These small changes produced no detectable change of slope when the uptake of $\mathrm{O}_{2}$ was plotted against time. With still lower $\mathrm{pO}_{2}$ values however, a decline in rate could be detected after $20 \mathrm{~min}$. In these cases only the initial rates were used.

In all cases respiration was expressed as $\mathrm{qO}_{2}\left(\mu \mathrm{l}\right.$. uptake of $\mathrm{O}_{2} / \mathrm{hr}$. $/ \mathrm{mg}$. dry-weight tissue). In the first experiment a temperature of $30^{\circ}$ was used. Later this was changed to $23^{\circ}$, the optimum for nitrogen fixation.

Gas mixtures. These were prepared from commercial gases through manifolds equipped with mercury manometers. The lines were evacuated by a rotary pump to $\mathbf{0 . 0 5} \mathrm{mm}$. Hg (McLeod gauge) and various scales graduated in percentage were used on the manometers according to the barometric pressure at the beginning of the experiment. Argon was used to bring the mixtures to one atmosphere. The following are mass spectrometric analyses of the gases used:

$$
\begin{array}{ll}
\text { Nitrogen } & \mathrm{N}_{2}(98 \cdot 2 \%), \mathrm{O}_{2}(0 \cdot 1 \%), \mathrm{A}(1 \cdot 7 \%) \\
\text { Argon } & \mathrm{A}(\mathbf{9 6 \cdot 3} \%), \mathrm{N}_{2}(3 \cdot 2 \%), \mathrm{O}_{2}(0 \cdot 5 \%) \\
\text { Oxygen } & \mathrm{O}_{2}(98 \cdot 7 \%), \mathrm{N}_{2}(1 \cdot 3 \%), \mathrm{A} \text { (trace) }
\end{array}
$$


For all purposes except the determination of the Michaelis constants, gas mixtures contained $10 \% \mathrm{~N}_{2}$.

Isotopic nitrogen $\left({ }^{15} \mathrm{~N}\right) .{ }^{15} \mathrm{~N}_{2}$ gas was prepared from $\mathrm{NH}_{3}$ (generated from $\mathrm{NH}_{4}^{+}$ labelled $\mathrm{NH}_{4} \mathrm{NO}_{3}$ ) by oxidation over $\mathrm{CuO}$ at $600-700^{\circ}$. The gas was passed through the oxidant for $\mathrm{l} \mathrm{hr}$. after constant volume was reached and was then collected over $\mathrm{Hg}$ after being circulated through a liquid $\mathrm{N}_{2}$ cooled trap where nitrogen-containing impurities condensed. Mass spectrometric analyses showed less than $1 \% \mathrm{O}_{2}$ and no trace of mass $31\left({ }^{15} \mathrm{NO}\right), 45$ or $46\left({ }^{14} \mathrm{~N}^{15} \mathrm{NO}\right.$ or $\left.{ }^{15} \mathrm{~N}_{2} \mathrm{O}\right)$ or $47\left({ }^{15} \mathrm{NO}_{2}\right)$.

Measurement of nitrogen fixation. Nodules were exposed at $\mathbf{2 3}^{\circ}$ to gas mixtures containing ${ }^{15} \mathrm{~N}_{2}$ in $50 \mathrm{ml}$. Erlenmeyer flasks attached to a manifold. After exposure, the nodules were crushed in $3 \mathrm{~N}-\mathrm{HCl}$ and the soluble material analysed for ${ }^{15} \mathrm{~N}$ after Kjeldahl digestion, distillation of $\mathrm{NH}_{3}$ and conversion of $\mathrm{NH}_{3}$ to $\mathrm{N}_{2}$ by alkaline $\mathrm{NaOBr}$ containing $0 \cdot 1 \% \mathrm{KI}$ (Francis, Mulligan \& Wormall, 1959). The atoms \% excess ${ }^{15} \mathrm{~N}$ in the samples was a measure of the nitrogen fixation of the nodules during their exposure to the labelled gas mixture.

Mass-spectrometric determinations. All isotope measurements and gas analyses were done with an M86 (Atlas-Werke, Bremen) mass spectrometer. Atoms $\%{ }^{15} \mathrm{~N}$ were determined from the mass $29: 28$ ratios of the samples and the excess calculated from alternative readings of a sample of air $\mathbf{N}_{2}$ contained in the other half of the double inlet system. All samples and standards were measured at the same inlet pressure $(5 \mathrm{~mm} . \mathrm{Hg}$ ). Corrections were made for air leakage occurring during preparation of the samples by measuring the magnitude of the mass 28 and 32 peaks and applying corrections to the atoms \% excess ${ }^{15} \mathrm{~N}$ (Francis et al. 1959). In these experiments the maximum analytical error of repeated determinations on the same sample of gas was $\pm 2 \%$ of the atoms \% excess. The maximum analytical error of a complete determination, including digestion, distillation, conversion to $\mathbf{N}_{2}$, measurement and correction was $\pm 6.5 \%$ of the atoms $\%$ excess. In any one experiment all values of ${ }^{15} \mathrm{~N}$ excess of samples were adjusted by multiplying by $c / x$ where $c$ was the chosen atoms $\%$ excess of the incubation gas mixture and $x$ was the actual value analysed. This step was necessary because contaminating $\mathrm{N}_{2}$ in the other gases used in the mixture caused small variations in the percentage of ${ }^{15} \mathrm{~N}$ in the mixtures of different composition which were used in an experiment; the step thus put all measurements on a common basis. Gas analyses were prepared from mass-spectra, the relative peak heights of which gave the partial pressures of the components of the mixture.

\section{RESULTS}

\section{The relationship between $p \mathrm{O}_{2}$ and $q \mathrm{O}_{2}$ for nodules and bacteroids}

The effect of nodule size and slicing. The general form of the effects of $\mathrm{pO}_{2}$ upon nodule respiration is seen in Fig. 1, which illustrates the results obtained with 23-day nodules. When $\mathrm{qO}_{2}$ was plotted against $\mathrm{pO}_{2}$ (the $\mathrm{qO}_{2} / \mathrm{pO}_{2}$ curve) the result was a distinct two-step curve with the first maximum at about $50 \% \mathrm{O}_{2}$ and the second at about $90 \% \mathrm{O}_{2}$. This type of curve was repeatedly obtained throughout this work as long as nodules of a single age were used. The plants from which the nodules used in this experiment were taken fell into two well-defined groups: those with few large (3-4 mm. diam.) nodules and those with many small (1.5-3 mm. diam.) ones. These nodules were of the same age to within one day and each plant bore the same 


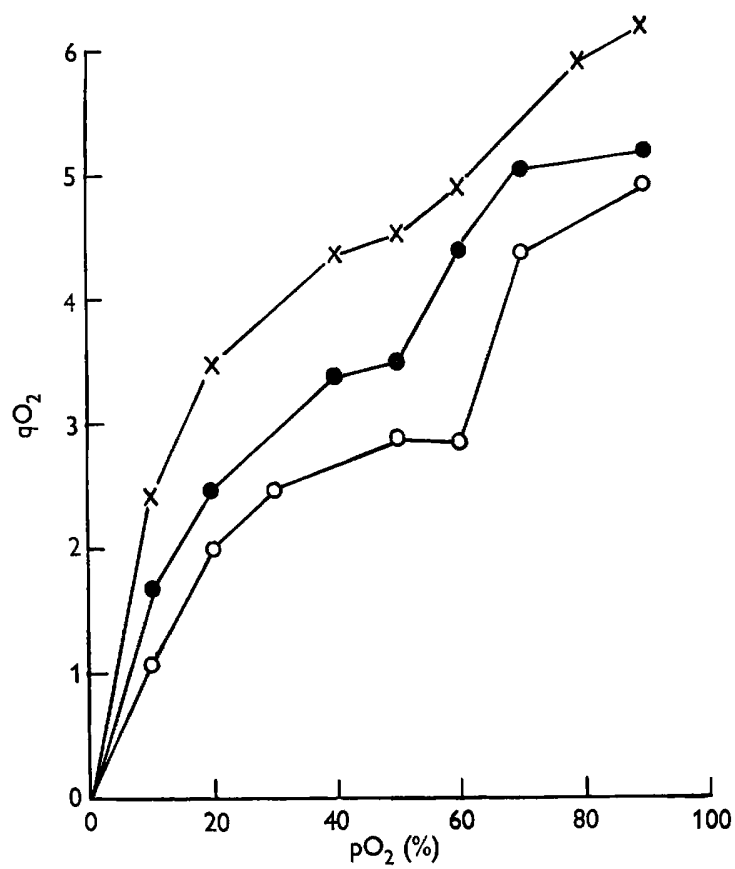

Fig. 1. The effects of nodule size and slicing on $\mathrm{qO}_{2} / \mathrm{pO}_{2}$ curves for nodules. Respiration

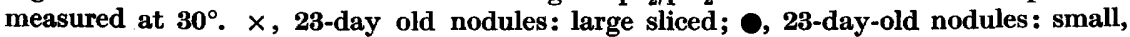
whole; O, 23-day-old nodules: large, whole.

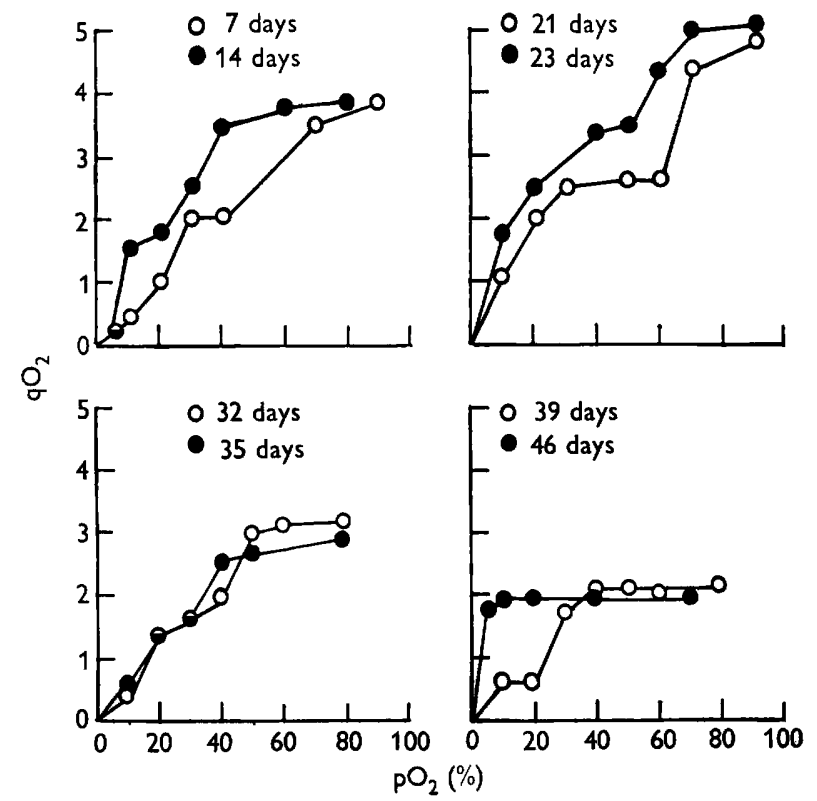

Fig. 2. The effects of nodule age on the $\mathrm{qO}_{2} / \mathrm{pO}_{2}$ curves for intact nodules, measured at $30^{\circ}$. 
weight of nodules. The effects of this difference in size are seen in Fig. 1. The small nodules had a slightly higher $\mathrm{qO}_{2}$ at each $\mathrm{pO}_{2}$ value and the maximum occurred at slightly lower $\mathrm{pO}_{2}$ than was the case for the large nodules. In all subsequent experiments only the large nodules were used because they were more easily handled.

When the large nodules were sliced (about $1 \mathrm{~mm}$. thick) the general form of the $\mathrm{qO}_{2} / \mathrm{pO}_{2}$ curve was still apparent, but the first maximum was not as marked as with the intact nodules and the $\mathrm{qO}_{2}$ at each $\mathrm{pO}_{2}$ value was raised. The magnitude of the first step of the curve was increased by a little more than a third and that of the second step was slightly reduced.

The effects of nodule age on the $q \mathrm{O}_{2} / \mathrm{pO}_{2}$ curve. The $\mathrm{qO}_{2} / \mathrm{pO}_{2}$ curves were determined for nodules of different ages. The results are illustrated in Fig. 2. The two-step curve was found at all ages except 46 days. With young nodules (7-14 days) the two

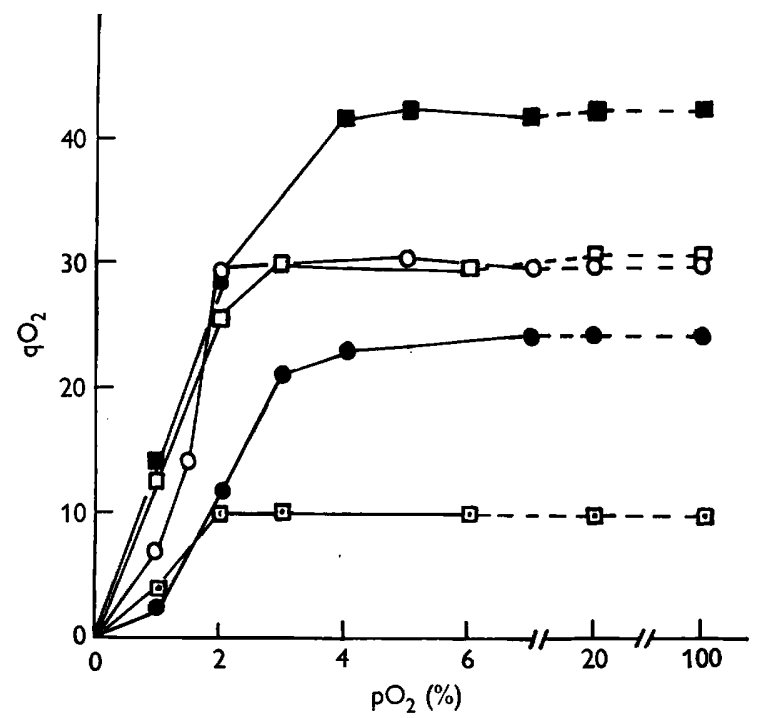

Fig. 3. The $\mathrm{qO}_{2} / \mathrm{pO}_{2}$ curves for bacteroids isolated from nodules of various ages. Bacteroids from nodules aged: 0,8 days, succinate;, 15 days, succinate; $\square, 22$ days, succinate; $\square, 47$ days, succinate; $\square, 22$ days, endogenous.

maxima occurred at lower $\mathrm{pO}_{2}$ values than with actively nitrogen-fixing (21-23 days) nodules. As the nodules aged, both maxima occurred at progressively lower $\mathrm{pO}_{2}$. At 46 days the first maximum, when present at all, occurred at less than $5 \% \mathbf{O}_{2}$ and nodule respiration was completely saturated with respect to $\mathrm{O}_{2}$ at $10 \%$. From previous work (Bergersen, 1958, 1960a) it is known that fixation ceases when the nodules are about 42 days old. Concurrently with this experiment measurements were made of the respiration of isolated bacteroids and the relative proportions of the various nodule fractions were determined.

The effects of nodule age on the $q \mathrm{O}_{2} / p \mathrm{O}_{2}$ curves for bacteroids. Bacteroids were prepared from nodules aged $8,15,22$ and 47 days and the respiration measured at a range of $\mathrm{pO}_{2}$ (Fig. 3). The maximum $\mathrm{qO}_{2}$ was attained at $2-3 \% \mathrm{O}_{2}$, and the curves are similar to those given by Burris \& Wilson (1939). The $\mathrm{qO}_{2} / \mathrm{pO}_{2}$ curves are typical of the saturation of an enzyme with increasing concentrations of its substrate and there was no evidence of a two-step curve as seen with intact nodules. The main 
effect of nodule age was that which has already been reported, as variations occurred in the maximum $\mathrm{qO}_{2}$ which were in close agreement with the results of Bergersen (1958). At all ages the endogenous respiration was one-third of the respiration with succinate as substrate and was very stable, the $\mathrm{qO}_{2}$ of 22-day-old bacteroids being unaltered after they had been standing in buffer at room temperature for $30 \mathrm{hr}$.

The effects of age on the composition of nodules. The composition of nodules is given in Table 1. For these determinations the nodules were crushed and the dry weights of the various fractions obtained after centrifugal separation. The nature of the fractions was checked microscopically. The composition became fairly stable from 15 days with the bacteroids making up about $25 \%$ of the dry weight and the cell walls and large particles of the host accounting for about $40 \%$.

Table 1. The composition of soybean root nodules of various ages determined on a dry-weight basis

\begin{tabular}{|c|c|c|c|c|c|}
\hline \multirow[b]{2}{*}{ Fraction } & \multicolumn{5}{|c|}{ Nodule age (days) } \\
\hline & 5 & 8 & $\stackrel{15}{\text { Fraction (\%) }}$ & 22 & $\mathbf{3 0}$ \\
\hline $\begin{array}{l}\text { Large particles } \\
\text { and cell walls (1) }\end{array}$ & 80 & 56 & 43 & 39 & 38 \\
\hline Bacteroids (2) & 3 & 19 & 28 & $\mathbf{2 5}$ & 25 \\
\hline Small particles (3) & 1 & 2 & 2 & $\mathbf{3}$ & $\mathbf{3}$ \\
\hline Soluble (4) & 15 & 23 & 26 & 26 & 26 \\
\hline
\end{tabular}

(1) Sedimented from nodules crushed in buffer at $300 \mathrm{~g}$ for $4 \mathrm{~min}$.

(2) Sedimented from the supernatant of (1) by $4000 \mathrm{~g}$ for $6-8 \mathrm{~min}$.

(3) Sedimented from the supernatant of (2) by $6000 \mathrm{~g}$ for $20 \mathrm{~min}$.

(4) Supernatant from (3).

\section{The effects of $\mathrm{pO}_{2}$ upon nitrogen fixation $\left({ }^{15} \mathrm{~N}_{2}\right.$ uptake)}

It has already been shown by Burris et al. (1955) that $\mathrm{pO}_{2}$ affects nitrogen fixation by excised soybean nodules, and it was necessary to ascertain that these effects were not due to an increase or a decrease in the time during which $\mathrm{N}$-fixing capacity was retained by the excised nodules. Figure 4 shows that this was not the case, since at 20,37 and $81 \% \mathrm{O}_{2}$, fixation was linear with time for at least $90 \mathrm{~min}$. No fixation at all was detected at $5 \% \mathrm{O}_{2}$; this is in agreement with all the present experiments, in which $\mathrm{N}_{2}$ fixation could be extrapolated to zero at about $5 \% \mathrm{O}_{2}$ for intact nodules. In this experiment, exposure to ${ }^{15} \mathrm{~N}_{2}$ commenced 55 min. after the first nodule was detached.

Nitrogen fixation increased with increasing $\mathrm{pO}_{2}$ up to $30^{\circ}-50 \%$, above which it was inhibited. With intact nodules, the rise in fixation with increasing $\mathrm{pO}_{2}$ from 10 to $50 \%$ was greater than the decrease which occurred from 50 to $80 \%$, but with sliced nodules the inhibition was as great as the stimulation over a similar increment of $\mathrm{pO}_{2}$ (Table 2; Fig. 5).

The effects of nodule age upon ${ }^{15} \mathrm{~N}$ uptake with different $\mathrm{pO}_{2}$ values. The amount of nitrogen fixed at the optimum $\mathrm{pO}_{2}$ varied with nodule age, being greatest at 28-32 days (Table 2), and the optimum $\mathrm{pO}_{2}$ decreased from $50 \%$ at 32 days to $30 \%$ at $\mathbf{4 0}$ days.

The relationship between the $q \mathrm{O}_{2} / \mathrm{pO}_{2}$ curve and ${ }^{15} \mathrm{~N}_{2}$ uptake with varying $p \mathrm{O}_{2}$. The 
data in Table 2 clearly show that the $\mathrm{pO}_{2}$ range of the first maximum of the $\mathrm{qO}_{2} / \mathrm{pO}_{2}$ curve corresponded with the $\mathrm{pO}_{2}$ range for maximum nitrogen fixation. Figure 5 illustrates the form of the curves for nodules aged 32 days. This relationship was not found in older nodules ( 86 and 40 days) when respiration was measured at $30^{\circ}$. In these cases the first maximum of the $\mathrm{qO}_{2} / \mathrm{pO}_{2}$ curve occurred at a lower $\mathrm{pO}_{2}$ than at $\mathbf{2 3}^{\circ}$ (compare Fig. 2 and Table 2 ).

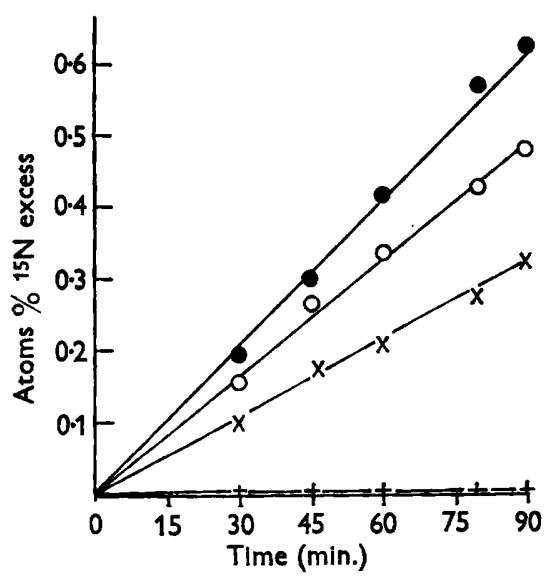

Fig. 4

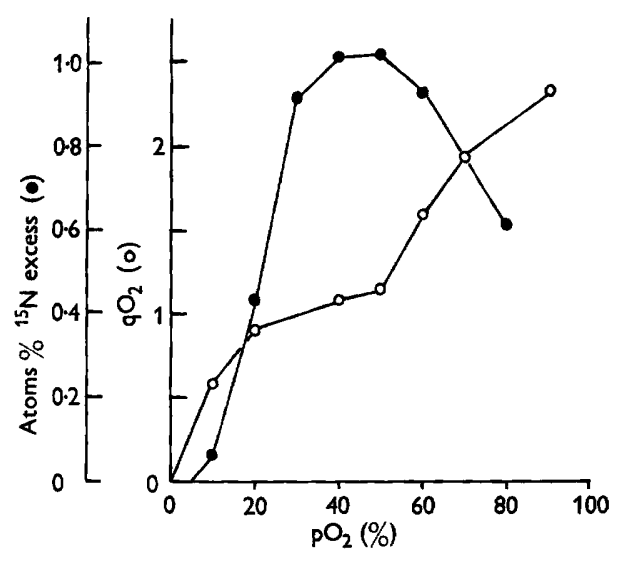

Fig. 5

Fig. 4. The time course of ${ }^{15} \mathrm{~N}_{2}$ uptake by 26 day old intact nodules. $, 37 \% \mathrm{O}_{2}, 0,81 \%$ $\mathrm{O}_{2}, \times, 20 \% \mathrm{O}_{2}, 10 \% ;+, 5 \% \mathrm{O}_{2}$, all gas mixtures contain $10 \%{ }^{15} \mathrm{~N}_{2}(46$ atoms $\%)$.

Fig. 5. The relationship between the $\mathrm{qO}_{2} / \mathrm{pO}_{2}$ curve and the nitrogen fixation $/ \mathrm{pO}_{2}$ curve for intact 32 day-old nodules. Both fixation and respiration measured concurrently at $\mathbf{2 3}^{\circ}$.

The effects of $\mathrm{pO}_{2}$ on the kinetics of nitrogen fixation. The kinetics of nitrogen fixation by intact nodules were examined by measuring the effect of $\mathrm{N}_{2}$ concentration upon the nitrogen fixed in $1 \mathrm{hr}$. with different $\mathrm{pO}_{2}$ values. The ${ }^{15} \mathrm{~N}$ excess of the nodules after $1 \mathrm{hr}$. was a valid measurement of the velocity $(v)$ at any particular $\mathrm{N}_{2}$ concentration $(s)$ since fixation was linear with time for at least $90 \mathrm{~min}$. The Dixon (1953) modification of the Lineweaver \& Burk (1934) graphical method was then used to determine the Michaelis constant $\left(K_{m}\right)$ and the maximum velocity $\left(V_{\max }\right)$ for nitrogen fixation in the Michaelis-Menten equation

$$
\frac{1}{v}=\frac{1}{V_{\max .}}+\frac{K_{m}}{V_{\max .}} \cdot \frac{1}{\mathrm{pN}_{2}}
$$

by plotting $1 / v$ against $1 / s$ at each $\mathrm{pO}_{2}$, for nodules aged from 25 to 27 days. The oxygen tension in this work as in the respiratory work was taken as the initial value. The $\mathbf{N}_{2}$ concentration was taken as the final $\mathrm{pN}_{2}$ measured in a gas sample taken at the end of the incubation. At each $\mathrm{pN}_{2}$ for any $\mathrm{pO}_{2}$, duplicate determinations of ${ }^{15} \mathrm{~N}$ excess were made on each of two separate samples of nodules.

Statistical methods were necessary in order to exploit the data fully. The following is an outline of the methods of analysis used as a result of examination of the form of the data. The variance of $1 / v$ increased with $1 / v$ so that a weighted regression procedure was necessary. To determine the weight function the regression of the 
difference between (or range of) the sample means of two duplicates on the average of the means was determined in a relationship of the form: range $=b_{1}(1 / v)+b_{2}(1 / v)^{2}$. This relationship itself was fitted using weights inversely proportional to $(1 / \text { range })^{2}$. The coefficient of the linear term, $b_{1}$, was significant while $b_{2}$ was not, although there is little doubt of the reality of the curvature. However, these data do not conform to a relationship: range $=b(1 / v)^{2}$, as suggested by Wilkinson (1961). The weights were taken as the inverse of the squares of the range estimated from the regression relation of any average $1 / v$. The weighted regression of $1 / v$ on $1 / \mathrm{pN}_{2}$ was fitted using standard least squares procedure. The confidence limits of the intercepts on the $x$ axis $\left(-1 / K_{m}\right)$ and on the $y$ axis $\left(1 / V_{\max }\right)$ were calculated using standard procedures.

Table 2. The influence of the partial pressure of $\mathrm{O}_{2}$ upon respiration and nitrogen fixation of excised soybean nodules of various ages

\begin{tabular}{|c|c|c|c|c|c|c|c|c|c|c|c|}
\hline \multirow{2}{*}{$\begin{array}{l}\text { Nodule } \\
\text { age } \\
\text { (days) }\end{array}$} & \multirow[b]{2}{*}{ Measurement } & \multicolumn{10}{|c|}{ Partial pressure of $\mathrm{O}_{2}(\%)$} \\
\hline & & $\mathbf{5}$ & 10 & 20 & 30 & 40 & 50 & 60 & 70 & 80 & 90 \\
\hline 23 & $\begin{array}{l}\mathrm{qO}_{2}^{*} \\
{ }^{15} \mathrm{~N} \text { excess } \dagger \\
\quad(\text { atoms } \%)\end{array}$ & $\begin{array}{l}- \\
-\end{array}$ & $\begin{array}{l}1 \cdot 66 \\
0 \cdot 064 \\
0 \cdot 060\end{array}$ & $\begin{array}{l}2 \cdot 48 \\
0 \cdot 202 \\
0 \cdot 156\end{array}$ & - & $\begin{array}{l}3 \cdot 41 \\
0 \cdot 626 \\
0 \cdot 766\end{array}$ & $\begin{array}{l}3 \cdot 60 \\
0 \cdot 653 \\
-\end{array}$ & $\begin{array}{l}4 \cdot 38 \\
0 \cdot 550 \\
0 \cdot 583\end{array}$ & $\begin{array}{l}5 \cdot 07 \\
0 \cdot 451 \\
0 \cdot 467\end{array}$ & $\begin{array}{l}-\overline{0} \\
0 \cdot 428 \\
0 \cdot 420\end{array}$ & $\begin{array}{c}5 \cdot 10 \\
-\end{array}$ \\
\hline $\begin{array}{c}23 \\
\text { (sliced) }\end{array}$ & $\begin{array}{l}\mathrm{qO}_{2}{ }^{*} \\
{ }^{15} \mathrm{~N} \text { excess } \dagger \\
\text { (atoms \%) }\end{array}$ & - & & & - & & & $\begin{array}{r}4.87 \\
-\end{array}$ & $\overline{0.811}$ & & $\begin{array}{l}23 \\
056\end{array}$ \\
\hline 28 & $\begin{array}{l}{ }_{15} \mathrm{O}_{2} \\
{ }^{15} \mathrm{~N} \text { excess } \dagger \\
\text { (atoms \%) }\end{array}$ & $\overline{-}$ & $\begin{array}{l}0 \cdot 40 \\
0 \cdot 188 \\
0 \cdot 199\end{array}$ & & - & & & $\begin{array}{l}1 \cdot 41 \\
1 \cdot 113 \\
-\end{array}$ & & - & $\begin{array}{l}1 \cdot 97 \\
0 \cdot 769 \\
0 \cdot 760\end{array}$ \\
\hline 32 & $\begin{array}{l}\mathrm{qO}_{2} \\
{ }^{15} \mathrm{~N} \text { excess } \\
\text { (atoms \%) }\end{array}$ & - & $\begin{array}{l}0.62 \\
0.067 \\
0.071\end{array}$ & $\begin{array}{l}0.81 \\
0.434 \\
0 \cdot 428\end{array}$ & $\begin{array}{l}-\overline{0.919} \\
0.921\end{array}$ & $\begin{array}{l}1 \cdot 04 \\
1 \cdot 105 \\
1 \cdot 116\end{array}$ & $\frac{1 \cdot 18}{1 \cdot 111}$ & $\begin{array}{l}1 \cdot 64 \\
0 \cdot 926 \\
0 \cdot 930\end{array}$ & $\begin{array}{r}1.94 \\
-- \\
-\end{array}$ & $\begin{array}{c}-\overline{0} \\
0 \cdot 613 \\
0 \cdot 609\end{array}$ & $\begin{array}{r}2 \cdot 31 \\
- \\
-\end{array}$ \\
\hline 36 & $\begin{array}{l}\mathrm{qO}_{2} \\
{ }^{15} \mathrm{~N} \text { excess } \\
\quad \text { (atoms \%) }\end{array}$ & $\overline{-}$ & $\begin{array}{l}0 \cdot 75 \\
0 \cdot 110 \\
0 \cdot 110\end{array}$ & $\begin{array}{l}1 \cdot 23 \\
0 \cdot 479 \\
0 \cdot 482\end{array}$ & $\begin{array}{l}1 \cdot 46 \\
0 \cdot 920 \\
0 \cdot 926\end{array}$ & $\begin{array}{l}1 \cdot 70 \\
1 \cdot 003 \\
1 \cdot 012\end{array}$ & $\frac{1 \cdot 68}{-}$ & $\begin{array}{l}2 \cdot 04 \\
0 \cdot 901 \\
0 \cdot 900\end{array}$ & - & $\begin{array}{l}2 \cdot 90 \\
0 \cdot 840 \\
0 \cdot 832\end{array}$ & $\begin{array}{c}- \\
0.780 \\
0.712\end{array}$ \\
\hline 40 & $\begin{array}{l}\mathrm{qO}_{2} \\
{ }^{15} \mathrm{~N} \text { excess } \\
\quad \text { (atoms \%) }\end{array}$ & $\frac{0.25}{-}$ & $\begin{array}{l}0 \cdot 68 \\
0 \cdot 019 \\
0 \cdot 019\end{array}$ & $\begin{array}{l}1 \cdot 37 \\
0 \cdot 195 \\
0 \cdot 205\end{array}$ & $\begin{array}{l}1.52 \\
0 \cdot 598 \\
0.629\end{array}$ & $\begin{array}{l}1 \cdot 80 \\
0 \cdot 598 \\
0 \cdot 559\end{array}$ & $\begin{array}{l}-\overline{0.531} \\
0.497\end{array}$ & $\begin{array}{l}2 \cdot 77 \\
0 \cdot 403 \\
0 \cdot 494\end{array}$ & - & $\begin{array}{l}2 \cdot 90 \\
0 \cdot 399 \\
0 \cdot 380\end{array}$ & - \\
\hline
\end{tabular}

$\mathrm{qO}_{2}=\mu \mathrm{l} . / \mathrm{hr} . / \mathrm{mg}$. dry wt. nodule. Respiration was measured on 20 nodules in each Warburg vessel; $0.5 \mathrm{ml} . \mathrm{M} / \mathbf{1 5}$ phosphate buffer ( $\mathrm{pH} 7 \cdot 0$ ), was added to prevent drying out of the tissue; centre wells contained $0.2 \mathrm{ml} 20 \% \mathrm{KOH}$.

${ }^{15} \mathrm{~N}$ uptake was measured by analysing the portion of the nodules which was soluble in $3 \mathrm{~N}-\mathrm{HCl}$ after $1 \frac{1}{2} \mathrm{hr}$. exposure at $23^{\circ}$ to gas mixtures enriched in ${ }^{15} \mathrm{~N}$. Figures for duplicate nodule samples are shown.

* The respiration of the 23-day-old nodules was measured at $30^{\circ}$. All other $\mathrm{qO}_{2}$ values shown were measured at $28^{\circ}$.

$\dagger$ Corrected ${ }^{15} \mathrm{~N}$ excess figures; all results are expressed as if the incubation gas contained $55 \cdot 8$ atoms $\%$ excess ${ }^{15} \mathrm{~N}$.

The results are given in Table 3. It will be seen that $V_{\max }$ increased with $\mathrm{pO}_{2}$. $K_{m}$ was only slightly affected by $\mathrm{pO}_{2}$ at the lower levels but above $40 \%$ increased very sharply. The intercepts on the $y$ axis for 60 and $80 \% \mathrm{O}_{2}$ were not significantly different but the slope was greater for $80 \% \mathrm{O}_{2}$. These results meet the criteria for competitive inhibition of nitrogen fixation by oxygen when comparing 60 and $80 \%$ $\mathrm{O}_{2}$. The intercepts on the $y$ axis for 50 and $60 \% \mathrm{O}_{2}$ were just significantly different, but the slope was greater for $60 \% \mathrm{O}_{2}$. Thus, comparing these two partial pressures 
of $\mathrm{O}_{2}$, the results approach competitive inhibition. The Dixon-Lineweaver-Burk plots for these three partial pressures of $\mathrm{O}_{2}$ are presented in Fig. 6.

Figure 7 shows the change in $K_{m}$ with $\mathrm{pO}_{2}$ and the change in nitrogen fixation at a constant $\mathrm{pN}_{2}(10 \%)$. These latter figures were determined from the regression diagrams of $1 / v$ on $1 / \mathrm{pN}_{2}$ at each $\mathrm{pO}_{2}$. Figure 7 thus shows the change in the kinetics of the nitrogen-fixation reaction in relation to the earlier experiments, in which the effects of $\mathrm{pO}_{2}$ upon fixation were determined with $\mathrm{pN}_{2}$ equal to $10 \%$ (Table 2 and Fig. 5).

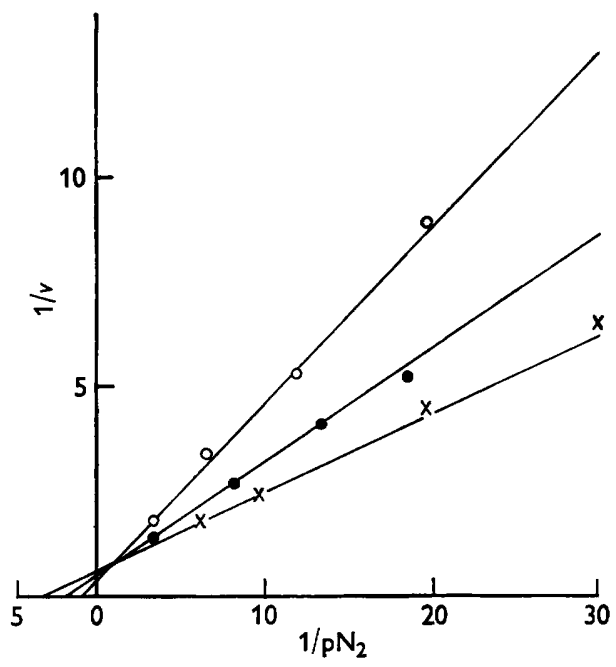

Fig. 6

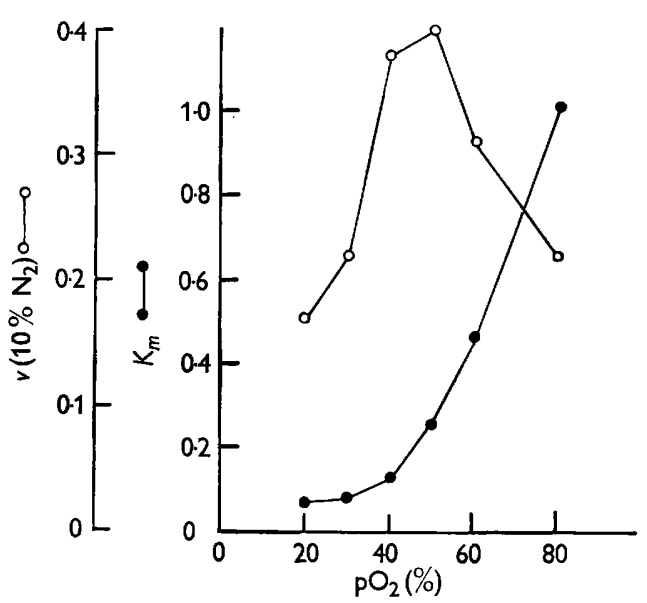

Fig. 7

Fig. 6. The Dixon-Lineweaver-Burk plot for nitrogen fixation by intact 26 day-old nodules at 50, 60 and $80 \% \mathrm{O}_{2}$. $\mathrm{O}-\mathrm{O}, 80 \% \mathrm{O}_{2} ;-\longrightarrow, 60 \% \mathrm{O}_{2} ; \times-\times, 50 \% \mathrm{O}_{2}$. Fig. 7. The relationship between the change in $K_{m}$ with $\mathrm{pO}_{2}$ and the change in fixation (v) with $\mathrm{pO}_{2}$ when the gas phase contained $10 \%{ }^{15} \mathrm{~N}_{2}$.

Table 3. Data from the Lineweaver-Burk plots of nitrogen fixation at different $\mathrm{pO}_{2}$ values. The intercepts on the $x$ axis gave $-1 / K_{m}$ and on the $y$ axis $1 / V_{\max }$.

\begin{tabular}{|c|c|c|c|c|c|c|c|c|}
\hline \multirow[b]{2}{*}{$\begin{array}{c}\text { Initial } \\
\mathrm{pO}_{2}(\%)\end{array}$} & \multicolumn{2}{|c|}{$1 / V_{\max .}$} & \multicolumn{2}{|c|}{$V_{\text {max. }}$} & \multicolumn{2}{|c|}{$-1 / \boldsymbol{K}_{m}$} & \multicolumn{2}{|c|}{$\underbrace{\boldsymbol{K}_{m}}$} \\
\hline & $\begin{array}{l}\text { Esti- } \\
\text { mate }\end{array}$ & $\begin{array}{c}95 \% \\
\text { limits }\end{array}$ & $\begin{array}{l}\text { Esti- } \\
\text { mate }\end{array}$ & $\begin{array}{c}95 \% \\
\text { limits }\end{array}$ & $\begin{array}{l}\text { Esti- } \\
\text { mate }\end{array}$ & $\begin{array}{l}95 \% \\
\text { limits }\end{array}$ & $\begin{array}{l}\text { Esti- } \\
\text { mate }\end{array}$ & $\begin{array}{l}95 \% \\
\text { limits }\end{array}$ \\
\hline 20 & $3 \cdot 4157$ & $\begin{array}{l}3 \cdot 9365 \\
2 \cdot 8949\end{array}$ & $0 \cdot 2927$ & $\begin{array}{l}0 \cdot 2540 \\
0 \cdot 3454\end{array}$ & 13.9361 & $\begin{array}{l}18 \cdot 8963 \\
10 \cdot 3181\end{array}$ & 0.0718 & $\begin{array}{l}0.0529 \\
0.0969\end{array}$ \\
\hline 30 & $2 \cdot 5058$ & $\begin{array}{l}3 \cdot 1368 \\
1 \cdot 8748\end{array}$ & 0.3991 & $\begin{array}{l}0 \cdot 3188 \\
0.5334\end{array}$ & $11 \cdot 8712$ & $\begin{array}{r}18 \cdot 2242 \\
7 \cdot 5261\end{array}$ & $0-0842$ & $\begin{array}{l}0.0549 \\
0.1329\end{array}$ \\
\hline 40 & $1 \cdot 1769$ & $\begin{array}{l}1 \cdot 5145 \\
0 \cdot 8393\end{array}$ & $0 \cdot 8497$ & $\begin{array}{l}0 \cdot 6603 \\
1 \cdot 1915\end{array}$ & $7 \cdot 8766$ & $\begin{array}{r}12 \cdot 7561 \\
4 \cdot 6755\end{array}$ & $0 \cdot 1269$ & $\begin{array}{l}0.0784 \\
0.2139\end{array}$ \\
\hline 50 & 0.7245 & $\begin{array}{l}0 \cdot 9440 \\
0 \cdot 5050\end{array}$ & $1 \cdot 3802$ & $\begin{array}{r}1.0593 \\
1.9802\end{array}$ & $3 \cdot 7775$ & $\begin{array}{l}5 \cdot 4518 \\
2 \cdot 4055\end{array}$ & $0 \cdot 2647$ & $\begin{array}{l}0 \cdot 1834 \\
0 \cdot 4.157\end{array}$ \\
\hline 60 & $0 \cdot 5660$ & $\begin{array}{l}0 \cdot 7168 \\
0 \cdot 4152\end{array}$ & 1.7667 & $\begin{array}{l}1 \cdot 3951 \\
2 \cdot 4085\end{array}$ & $2 \cdot 1954$ & $\begin{array}{l}3.0111 \\
1.4992\end{array}$ & 0.4554 & $\begin{array}{l}0 \cdot 3321 \\
0 \cdot 6670\end{array}$ \\
\hline 80 & 0.4036 & $\begin{array}{l}0 \cdot 6247 \\
0 \cdot 1825\end{array}$ & $2 \cdot 4777$ & $\begin{array}{l}1.6008 \\
5 \cdot 4795\end{array}$ & 0.9402 & $\begin{array}{l}1 \cdot 5798 \\
0 \cdot 3954\end{array}$ & $1 \cdot 0636$ & $\begin{array}{l}0 \cdot 6330 \\
2 \cdot 5291\end{array}$ \\
\hline
\end{tabular}




\section{DISCUSSION}

There are intriguing effects of oxygen tension both on nodule respiration and on nitrogen fixation. In discussing these results it is convenient to divide this part of the paper into sections, but it should be realized that the results are composed of inter-related observations.

The effects of $\mathrm{pO}_{2}$ on nodule respiration. In the widest sense the results presented are in agreement with the work of others (e.g. Allison et al. 1940; Ebertova, 1959) who have concluded that the oxygen tension in legume root nodules in air is low. This is shown by the 2-3-fold increase in $\mathrm{qO}_{2}$ when the external $\mathrm{pO}_{2}$ is increased from air tension $(20 \%)$ to $90 \%$. The additional information which has come from the present work is that this increase in respiration is not simple. The failure of others to observe the two-step nature of the $\mathrm{qO}_{2} / \mathrm{pO}_{2}$ curve can be attributed largely to the fact that no precautions were taken about nodule age. Nodules of a range of ages would have the first maximum at different $\mathrm{pO}_{2}$ values and hence the whole curve would tend to be smoothed out. An explanation of the $\mathrm{qO}_{2} / \mathrm{pO}_{2}$ curve is offered.

Interpretation of the nodule respiration data. From studies of the anatomy and cytology of soybean nodules the bacteroids are seen to be the innermost component since in the central tissue in which they occur they are enclosed within membrane envelopes in the cytoplasm of the host cells (Bergersen \& Briggs, 1958). It may also be noted again that the tissues of soybean nodules are uniform in cell age since these nodules have no growing point (Bergersen, 1958). From these considerations and assuming (i) that bacteroids within the nodules have a $\mathrm{qO}_{2}$ similar to their endogenous $\mathrm{qO}_{2}$ as measured in the Warburg; and (ii) that root tissue has a similar $\mathrm{qO}_{2}$ to the plant tissue component of nodules, it is possible to offer an explanation of the unusual pattern of nodule respiration with increasing $\mathrm{pO}_{2}$. Because the bacteroids are the innermost respiring component it is logical to suggest that their respiration is the last to be saturated with respect to $\mathrm{O}_{2}$ as the external $\mathrm{pO}_{2}$ increases; that is to say, the second step of the $\mathrm{qO}_{2} / \mathrm{pO}_{2}$ curve for the nodules represents the bacteroid respiration increasing to a maximum with increased penetration of $\mathrm{O}_{2}$. Table $\mathrm{I}$ shows that for nodules aged 22 days the bacteroids composed $25 \%$ of their dry weight. Figure 3 shows that the maximum respiration of bacteroids isolated from these nodules occurs at $2-3 \% \mathrm{O}_{2}$. If we now consider the data for nodules aged 21 days (Fig. 2), the bacteroids (22-day sample, Fig. 3) respiring at the maximum endogenous rate would account for $2.5 \mu \mathrm{l}$. $/ \mathrm{hr}$. of $\mathrm{O}_{2}$ uptake. This is the magnitude of the second step of the $\mathrm{qO}_{2} / \mathrm{pO}_{2}$ curve (Fig. 2, 21 days).

Turning to the plant tissue component of the nodule respiration, it is seen that this is made up of the respiration of the cortical tissue and the central (bacteroidcontaining) cells, the peripheries of which contain mitochondria (unpublished electron microscope observations). It was found that 23-day soybean root segments had a $\mathrm{qO}_{2}$ of $2 \cdot 52$ at $20 \% \mathrm{O}_{2}$ and $3 \cdot 36$ in $100 \% \mathrm{O}_{2}$. These values are close to those of Allison et al. (1940), namely, $2 \cdot 12$ and $2 \cdot 88$, respectively. They support the suggestion that the first part of the $\mathrm{qO}_{2} / \mathrm{pO}_{2}$ curve represents the saturation with $\mathrm{O}_{2}$ of the plant tissue respiration of the nodule, because $75 \%$ of the nodule dry weight is plant tissue and $75 \%$ of $3 \cdot 36$ (the maximum $\mathrm{qO}_{2}$ of root tissue) is close to the magnitude of the first maximum of the curve for these nodules (Fig. 2). The suggested explanation is summarized in Fig. 8, which shows how the nodule $\mathrm{qO}_{2} / \mathrm{pO}_{2}$ curve 
could be the sum of the respiration of the plant tissue and of the bacteroids as the respirations of these components are successively saturated with $\mathrm{O}_{2}$.

Assuming that this interpretation is correct, it is also possible to deduce the internal $\mathrm{pO}_{2}$ at various external oxygen tensions. These deduced values are shown on the lower scale of Fig. 8.

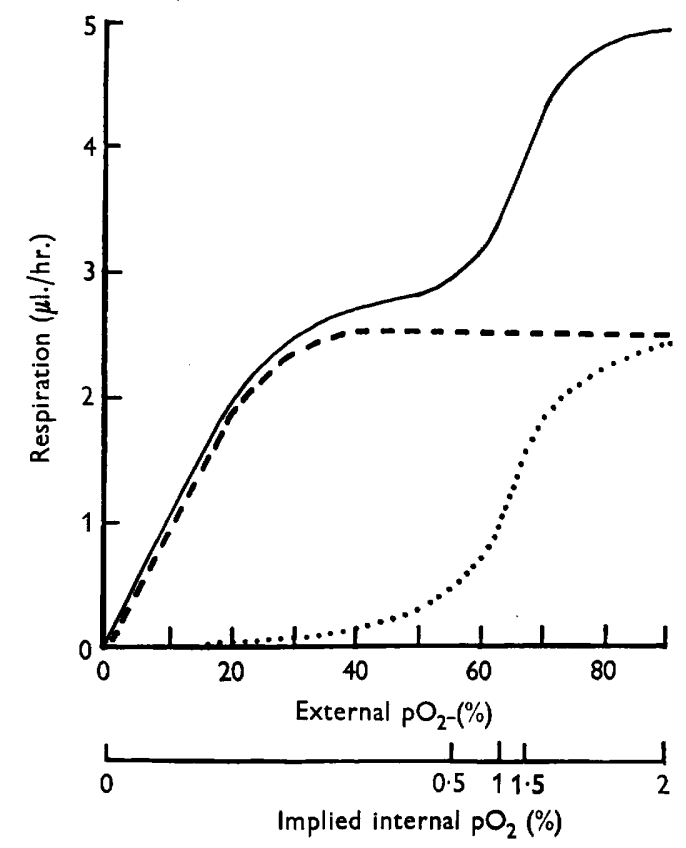

Fig. 8. The explanation of the $\mathrm{qO}_{2} / \mathrm{pO}_{2}$ curve for nodules. The observed curve is considered to be the sum of the curves for the plant tissue and the bacteroids as these are successively saturated with respect to $\mathrm{O}_{2}$. - - Observed respiration $1 \mathrm{mg}$. nodules aged 21 days; --- , observed respiration $0 \cdot 75 \mathrm{mg}$. root aged 21 days; $\cdots . .$. , calculated respiration $0.25 \mathrm{mg}$. bacteroids.

This explanation of the nodule respiration data implies that there is an $\mathrm{O}_{2}$ diffusion barrier between the host respiration and that of the bacteroids. The latter, with their high respiratory rate (about five times higher than that of the root tissue cells in terms of the dry weight) would respire any $\mathrm{O}_{2}$ passing the outer respiring regions of the nodule as, with increasing external $\mathrm{pO}_{2}$, these regions approached saturation with respect to $\mathrm{O}_{2}$. There would be no break in the curve unless there was a further barrier which did not permit the passage of appreciable amounts of $\mathrm{O}_{2}$ until a certain partial pressure had been exceeded. This diffusion barrier may be the membrane envelopes within which the bacteroids are enclosed (Bergersen \& Briggs, 1958).

The effects of $\mathrm{pO}_{2}$ upon nitrogen fixation. The data of Table 2 fully agree with those of Burris et al. (1955) who found similar responses to increased $\mathrm{pO}_{2}$ with sliced nodules. However, in my work there was considerably less variation in ${ }^{15} \mathbf{N}_{2}$ uptake than was the experience of these authors or of Aprison, Magee \& Burris (1954), who found it necessary to use sliced nodules to decrease variation. This decreased variability of nitrogen fixation in the present work is attributable once again to the use 
of nodules of a single age in any one experiment. The use of nodules of mixed ages and of successive nodule samples from ageing plants will give rise to errors because the shape of the fixation $/ \mathrm{pO}_{2}$ curve changes with age.

The nature of the stimulation of nitrogen fixation with increased $\mathrm{pO}_{2}$ up to about $50 \%$ in any one nodule sample remains obscure. The increased respiration of the host tissues in this $\mathrm{pO}_{2}$ range may provide more substrates to the bacteroids or more acceptors for the fixed nitrogen. There is a significant correspondence between the first maximum of the $\mathrm{qO}_{2} / \mathrm{pO}_{2}$ curve and the optimum $\mathrm{pO}_{2}$ for nitrogen fixation (Fig. 5). If the interpretation of the respiratory data which has been offered is correct, it would therefore seem that the penetration of $\mathrm{O}_{2}$ into the vicinity of the bacteroids results in inhibition of nitrogen fixation. This has been confirmed by the kinetic data.

Parker \& Scutt (1960) showed that, within certain limits, $\mathrm{O}_{2}$ and $\mathrm{N}_{2}$ competed as terminal hydrogen acceptors in nitrogen fixation by Azotobacter vinelandii and thus fixation may be regarded as a form of respiration. That a similar phenomenon might account for the inhibition of nodule nitrogen fixation at high $\mathrm{pO}_{2}$, described by Burris et al. (1955), has been suggested by Bergersen (1960b). The kinetic studies reported here show that there was in fact a competitive inhibition of nitrogen fixation by $\mathrm{O}_{2}$ at high external $\mathrm{pO}_{2}$. The value for $K_{m}$ of 0.07 atmosphere $\mathrm{N}_{2}$ for $20 \% \mathrm{O}_{2}$ is higher than the 0.025 obtained by Burris et al. (1955), probably because they used sliced rather than intact nodules. The Michaelis constant $\left(K_{m}\right)$ also rose sharply in a range at which an internal $\mathrm{O}_{2}$ diffusion barrier became permeable. The competitive nature of the inhibition is not necessarily due to a direct competition for the active site of the nitrogen-reducing enzyme. Any diversion of reducing power from any part of an electron transport chain could have a competitive effect. Thus, diversion of the bacteroid-reducing power to aerobic respiration could have a competitive effect even if the actual reduction of nitrogen or nitrogen containing intermediate compounds took place at a site remote from the bacteroids but linked with them by an electron transport chain. The results reported in the present work therefore support the hypothesis proposed elsewhere (Bergersen $1960 b$ ), that one of the main functions of the bacteroids in nodule nitrogen fixation is that they are a source of reducing power which is used for the ultimate reduction of $\mathrm{N}_{2}$ to $\mathrm{NH}_{3}$.

The statistical analyses of the kinetic data were done by Messrs G. A. McIntyre and N. L. Dudzinski (Division of Mathematical Statistics, C.S.I.R.O., Canberra) to whom thanks are due. The technical assistance of Mrs M. Stiller is gratefully acknowledged. The isotopic work was made possible by a generous grant from the Rockefeller Foundation, New York.

\section{REFERENCES}

Aluison, F. E., Ludwig, C. A., Hoover, S. R. \& Minor, F. W. (1940). Biochemical nitrogen fixation studies. I. Evidence for limited oxygen supply within the nodule. Bot. Gaz. 101, 513.

Aprison, M. H., Magee, W. E. \& Burris, R. H. (1954). Nitrogen fixation by excised soybean nodules. J. biol. Chem. 208, 29.

Bergersen, F. J. (1958). The bacterial component of soybean root nodules; changes in respiratory activity, cell dry weight and nucleic acid content with increasing nodule age. J. gen. Microbiol. 19, 312. 
Bergersen, F. J. \& Briggs, M. J. (1958). Studies on the bacterial component of soybean root nodules; cytology and organization in the host tissue. J. gen. Microbiol. 19, 482.

Bergersen, F. J. $(1960 a)$. Incorporation of ${ }^{15} \mathrm{~N}$ into various fractions of soybean root nodules. J. gen. Microbiol. 22, 671 .

Bergersen, F. J. (1960b). Biochemical pathways in legume root nodule nitrogen fixation. Bact. Rev. 24, 246.

Bond, G. (1961). The oxygen relation of nitrogen fixation in root nodules. Z. allg. Mikrobiol. $1,93$.

Burris, R. H., Magee, W. A. \& BaCh, M. K. (1955). The $\mathrm{pN}_{2}$ and the $\mathrm{pO}_{2}$ function for nitrogen fixation by excised soybean nodules. In Biochemistry of Nitrogen, p. 190. Helsinki : Suomalainen Tiedeakatemia.

Burris, R. H. \& Wilson, P. W. (1939). Respiratory enzyme systems and symbiotic nitrogen fixation. Cold Spr. Harb. Symp. quant. Biol. 7, 349.

Dixon, M. (1953). The determination of enzyme inhibitor constants. Biochem. J. 55, 170.

Emertova, H. (1959). Redox potentials in soybean nodules during the vegetative period. Nature, Lond. 184, 1046.

Ferguson, T. P. \& Bond, G. (1954). Symbiosis of legume plants and nodule bacteria. V. The growth of red clover at different oxygen tensions. Ann. Bot. 18, 385.

Francis, G. E., Mulligan, W. \& Wormall, A. (1959). Isotopic Tracers. London: University of London, The Athlone Press.

Lineweaver, H. \& BurK, D. (1934). The determination of enzyme dissociation constants. J. Amer. chem. Soc. 56, 658.

Parker, C. A. \& Scutt, P. B. (1960). The effect of oxygen on nitrogen fixation by Azotobacter. Biochim. biophys. Acta, 38, 230.

Wilkinson, G. N. (1961). Statistical estimations in enzyme kinetics. Biochim. J. 80, 324. 